TAPROBANICA, ISSN 1800-427X. August, 2014. Vol. 06, No. 02: pp. 137-139, pl. 15.

(C) Research Center for Climate Change, University of Indonesia, Depok, Indonesia

\& Taprobanica Private Limited, Homagama, Sri Lanka

http://www.sljol.info/index.php/tapro

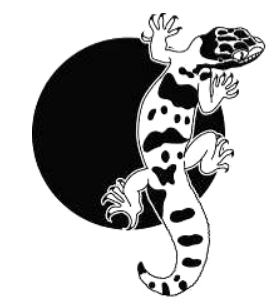

\section{Cyperus papyrus L. (Cyperaceae): a new record for Western Ghats, India}

Cyperus L. (Cyperaceae) contains about 600 species and distributed mainly in the tropics (Tucker et al., 2002). In India, it is represented by 70 species (Prasad \& Singh, 2002), of which 48 are found in Kerala State (Nayar et al., 2006: 670-677). It is a taxonomically complex genus and the treatment of Cyperus by Kuekenthal in 1935-1936 is considered to be an useful treatment even now. They usually grow in wetland vegetation, mud banks, open areas, etc.

While studying the sedge flora of Nilgiri Biosphere Reserve, the authors collected an interesting species of Cyperus, from the Western Ghats in the Wayanad District, Kerala State. On examination, the species was identified as Cyperus papyrus L., a naturalised ornamental in Africa and North America (Cook, 1996: 118-119). Scrutiny of the literature revealed that it was not reported from Western Ghats earlier but known from Gujarat and Rajasthan, India (Cook, 1996.; Kumar, 2011). Hence, the present collection forms a new distributional record for Western Ghats and also an addition to the flora of the region. It is described with photographs and relevant notes to facilitate its easy identification in the field.

Cyperus papyrus L., Sp. Pl. 1: 47.1753. Papyrus antiquorum Willd., Abh. Königl. Akad. Wiss. Berlin 1812-1813: 70. 1816, nom. illeg. Papyrus siculus Parl., Hooker's J. Bot. Kew Gard. Misc. 3.189. 1851.

Plants robust perennials. Rhizomes creeping, $3-6 \mathrm{~cm}$ thick, densely covered by $2-7 \times 1-2 \mathrm{~cm}$ wide blackish scales. Culms solitary or nearly so, erect, 1-5 $\mathrm{m}$ tall, 3-sided with rounded angles, green; base suberect. Leaves bladeless on culms; sheaths $10-30 \times 2-6 \mathrm{~cm}$, blackish or reddish-brown, becoming woody below; sterile shoots with leaf blades up to $8 \mathrm{~mm}$ wide. Involucral bracts up to 12 , much shorter than the inflorescence, 5-10 $\times 1-3 \mathrm{~cm}$, light brown, pale green. Inflorescence compound, spreading, umbel-like with 30-100 subequal rays, $10-80 \mathrm{~cm}$ long; secondary rays $3-5 \mathrm{~cm}$ long. Spikes cylindrical, $1-3 \times 0.6-1.2 \mathrm{~cm}$, bearing many spikelets. Spikelets cylindrical or slightly flattened, 3-12 × 0.7-1 mm, 5-17flowered. Glumes elliptical to ovate-elliptical, 2-2.5 mm long, light brown to golden, obtuse apically, often emarginate with a minute mucro, deciduous; keel green, 3-nerved; rachilla slender with yellow, lanceolate wings, falling early with glumes. Stamens 3; anthers linear oblong with an acute crest. Ovary $0.8-1 \mathrm{~mm}$; styles ca. $0.8 \mathrm{~mm}$ long; stigmas 3 . Nuts ellipsoid, trigonous, $\quad 0.9-1.1 \times 0.4-0.5 \mathrm{~mm}$ wide, smooth, dark brown to dark grey (Fig 1).

Specimen examined: INDIA, Kerala, Wayanad District, Maniyancodu, $11^{\circ} 37^{\prime} 51.0^{\prime \prime} \mathrm{N}$, $76^{\circ} 04^{\prime} 04.2^{\prime \prime} \mathrm{E}, \pm 726 \mathrm{~m}, 12$ Oct 2012, A.R. Viji \& A.G. Pandurangan 73988 (TBGT).

\section{Flowering \& Fruiting: August-December}

Habitat: In its natural habitats Cyperus papyrus occurs in large dense populations in swamps.

Distribution: Cyperus papyrus is widely distributed in the Nile River Valley of northern Africa, Madagascar and the Mediterranean countries (Kuekenthal, 1935-1936; De Flippis, 1980; Gordon-Gray, 1995; Mabberley, 1997). In South Africa, it is limited to the lower altitude and warmer parts of Namibia, Botswana, Limpopo, Mpumalanga and Kwa Zulu-Natal. It is naturalised in Sicily and in Florida in USA (Wunderlin, 1998). It also extended its distribution into Indonesia, Israel, Syrian Arab Republic, Taiwan, China and elsewhere. In India it is reported from Gujarat and Rajasthan (Cook, 1996). 
Note I: This large, emergent, aquatic perennial may grow to more than $5 \mathrm{~m}$ high, making it one of the largest sedges in the world. The culms can be so dense and impossible to penetrate by human that the species is an ideal candidate for biofencing. The most conspicuous features of Cyperus papyrus are the bright, green, smooth, bladeless flowering culm and the "featherduster" flowering head.

Note II: Cyperus papyrus was first exploited ca. 4500 years ago by the ancient Egyptians to manufacture paper (Levitin \& Mc Mahon, 2003). The English word 'paper' is derived from 'papyrus' the Latin name for this species. It provides food, fodder, fuel, and weaving materials. The pith of young shoots and starchy rhizomes are eaten both cooked and raw by humans. Its woody rhizomes and culms are made into bowls, reed boats, mats, cloth, cordage, and sandals. It is also used in Africa as a fuel source and is cultivated throughout the tropics and in conservatories in temperate regions as an ornamental for ponds. The young shoots are frequently grazed by live stock. They are significant, often dominant components of many types of wetlands throughout the world, both tropical and temperate. Papyrus swamps and the "featherduster" flowering head, provide important habitat for several bird species, some of which are endangered. The nuts are important food for many migratory birds, aquatic and amphibious animals (Liberty Hyde Bailey Hortorium, 1976; Chapman et al., 1996; Cook, 1996; Boar et al., 1999; Reznick, 2013)

\section{Acknowledgements}

The authors are grateful to P. G. Latha (Director, JNTBGRI) for facilities and encouragements. The State Forest authorities are duly acknowledged for giving permission to conduct field studies.

\section{Literature cited}

Boar, R. R., D. M. Harper, and C. S. Adams, 1999. Biomass allocation in Cyperus papyrus in tropical wetland, Lake Naivasha, Kenya. Biotropica, 3: 411-421.

Chapman, L. J., C. A. Chapman, R. OgutuOhway, M. Chandler, L. Caulfman, and A. E. Keiter 1996. Refugia for endangered fishes from an introduced predator in Lake Nebugabo, Uganda. Conservation Biology, 10: 554-561.
Cook, C. D. K., 1996. Aquatic and Wetland Plants of India. Oxford University Press, New York: 385.

De Filipps, R. A., 1980. Cyperus. In: Tutin, T. G., V. H. Heywood, N. A. Burges, D. M. Moore, D. H. Valentine, S. M. Walters, and D. A. Webb. (eds.). Flora Europea. Cambridge University Press, Cambridge. 5: 284-288.

Gordon-Gray, K. D., 1995. Cyperaceae in Natal. National Botanical Institute, Pritoria, South Africa: 218.

Kuekenthal, G., 1935-36. Cyperaceae Scirpoideae-Cyperae. In: A. Engler (ed.). Das Pflanzenreich IV, 20 (Heft 101). Wihelm Engleman, Leipzig: 1-671.

Kumar, B., 2011. Cyperus papyrus. In: IUCN 2013. IUCN Red List of Threatened Species. Version 2013.2. <www.iucnredlist.org>. Accessed on 18 December 2013.

Liberty Hyde Bailey Hortorium, 1976. Hortus third. Macmillan Publishing company, Inc., New York. 1290 pp.

Nayar, T. S., A. Rasiya Beegam, N. Mohanan, and G. Rajkumar, 2006. Flowering Plants of Kerala - A Handbook. Tropical Botanic Garden \& Research Institute, Palode, Thiruvananthapuram, Kerala: 1069.

Levitin, E. and K. Mc Mahon, 2003. Plants and Society. Ed. 3. Mc Graw-Hill Companies, Inc. New York: 508.

Mabberley, D. J. 1997. The Plant Book. A Portable Dictionary of the Vascular Plants. Ed. 2. Cambridge University Press, Cambridge: 865.

Prasad, V. P. and N. P. Singh, 2002. Sedges of Karnataka (India). Scientific Publishers, Jodhpur: 354.

Reznicek, A. A., 2013. Cyperaceae. Encyclopaedia Britanica.<http://www.britannica. com/EBchecked/topic/148485/Cyperaceae>

Accessed on 18 December 2013.

Tucker, G. C., B. G. Marcks, and J. R. Carter, 2002. Cyperus. In: Flora of North America Editorial committee (eds.). Flora of North America North of Mexico. Magnoliophyta: Commelinidae (in part): Cyperaceae. Oxford University Press, New York. 23: 14-91. 
Wunderlin, R. P., 1998. Guide to the vascular plants of Florida. Univ. Press, Florida, Gainesville: 806.

Submitted: 19 Dec. 2013, Accepted: 17 Jan. 2014 Sectional Editor: James L. Reveal

A. R. Viji ${ }^{1}$, S. Deepu ${ }^{1} \&$ A. G. Pandurangan ${ }^{1,2}$

${ }^{1}$ Jawaharlal Nehru Tropical Botanic Garden \& Research Institute, Palode, Thiruvananthapuram 695562, Kerala, India

2agpandurangan@gmail.com 


\section{PLATE 15}
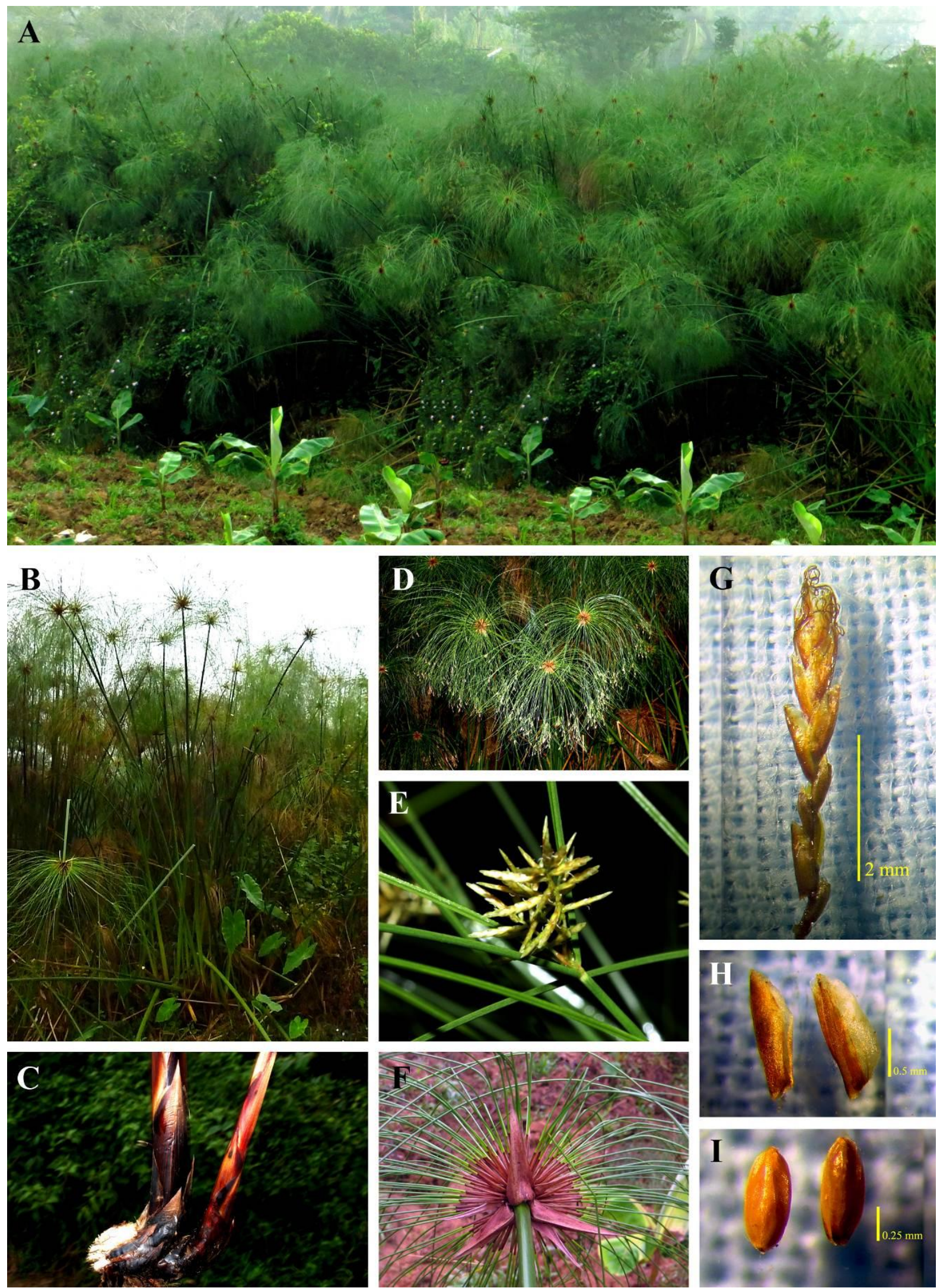

Figure 1: Cyperus papyrus L. A, Habitat; B, Habit; C, Rhizome; D, Inflorescence; E, Spikelet cluster; F, Bract; G, Spikelet; H, Glumes; I, Seeds. 